\title{
Defence mounted for research in biological warfare
}

\section{Washington}

MilitARy and government officials squared off against environmentalists and medical professionals over the propriety of the Army's biological defence programme at a congressional hearing last week. At issue is whether the Army has crossed the fine line between defensive and offensive weapons research.

Controversy over the Army's biological defence programme has come to a head since the Army lost a lawsuit in 1985 brought by Jeremy Rifkin's Foundation on Economic Trends. As a result, the Army had to file an environmental impact assessment of its plans for a high-containment biological research facility at the Dugway Proving Ground, Utah. Plans for the facility include the testing of protec-

\section{South African minister backs down}

Oxford

SouTH Africa's Minister of National Education, F.W. de Klerk, seems finally to have backed down in his efforts to impose subsidy conditions on the country's universities. This follows rulings of both the Cape and Natal divisions of the Supreme Court that the regulations imposing subsidy conditions, promulgated in October last year, were ultra vires.

It was feared that de Klerk might respond by amending the Universities' Act, but last week, in his budget vote in parliament, he said that the letters sent to the universities last October outlining the subsidy conditions were to be withdrawn. Instead he announced that the government would enter into negotiations with the universities to achieve consensus on the issue of campus discipline. The universities of Cape Town and the Witwatersrand have welcomed his proposals.

There has been speculation that the real reason de Klerk has backed down may relate to the fact that the different universities fall under the control of several ministers of education (see Nature 331, 104; 1988). Although the government would have no trouble effecting amendments in the 'white' chamber of parliament, these would have to be ratified by the 'Indian' and 'coloured' chambers in order to apply to the universities of Durban-Westville and the Western Cape, respectively. Given recent disagreements between President Botha and the leader of the majority party in the 'coloured' chamber, Rev. Hendrickse, de Klerk's amendments may well not have been assured of much support there.

Michael Cherry tive gear against pathogen aerosols and the development of vaccines and treatments to protect troops against biological weapons on the battlefield. The Army filed its assessment with the Environmental Protection Agency three months ago.

The agency has responded by requesting the Army to provide more information on the use of non-pathogenic 'simulant' organisms as options to reduce risk; to detail more fully security measures to safeguard the installation against sabotage or terrorism; and to provide additional justification for the highest biosafety level status, if it contends that research requiring such maximum containment will not be conducted. Rifkin has also pressured the Army into preparing an environmental impact statement, due this month, covering all the Army contractors conducting biological weapons research.

The United States cannot produce or stockpile biological weapons under the 1972 Biological Weapons Convention, signed by 103 nations including the Soviet Union. But because the treaty contains no provisions for verification, it allows research on virulent microorganisms and toxins for "prophylactic, protective, or other peaceful purposes".

The United States has accused the Soviet Union of using mycotoxins, or 'yellow rain', in Afghanistan and SouthEast Asia, and points to a mysterious outbreak of anthrax in Sverdlovsk in 1979 as evidence that the Soviets are developing biological weapons. The Soviets have repeatedly denied the allegations.

In his testimony before the joint meeting of three congressional subcommittees, Thomas J. Welch, deputy assistant to the Secretary of Defense, said the number of countries capable of waging war using biological weapons has increased to 10 in recent years. Because several of them are unfriendly to the United States and are on the State Department's list of countries that harbour international terrorists, he said "we . . . have the responsibility to the soldier" to develop defence mechanisms.

But public health witnesses, including Anthony Robbins of the Committee for Responsible Genetics and Jay A. Jacobson of the University of Utah School of Medicine, argued that the diversity of agents that could be used as biological weapons and the many methods for deploying them prevent the realistic development of defence strategies. Instead, they countered, the Army's work in testing actual pathogens against potential defences could be construed by other countries as offensive research. They also argued that the $\$ 300$ million project planned for Dugway is wasteful, considering that no effective defence can be developed, and that the risks, should one of the organisms being studied escape, are too high.

Carol Ezzell

\section{Critical report on European fusion 'misses the point'}

\section{London}

BRITISH fusion researchers have reacted with anger and incredulity to criticisms levelled at the joint European fusion programme, based mainly at Culham in England. A report commissioned by the European Parliament's Scientific and Technological Options Assessment project (STOA) casts doubt on the eventual feasibility of fusion as a viable source of power and implies that the large sums spent on the programme could probably be better deployed elsewhere. "Forecasts about fusion have become couched in an aura of over-optimism. With the resulting risk that serious errors of judgement can be made and, in our view, are being made."

The report, by Colin Sweet, of the London-based Centre for Energy Studies, comes at a particularly sensitive time, with budget wranglings already threatening to delay the fusion programme. The European Commission has yet to approve the proposed fusion budget of 911 million ECU (European currency units; $1 \mathrm{ECU}=$ $£ 0.69$ ) to 1991. Sweet's principal conclusion is that "a full and proper economic evaluation is overdue" and that such an evaluation be made a condition of the allocation of any resources beyond 1991 . The report expresses doubt that the present system for review, by the commission's own fusion directorate, would provide the necessary degree of objectivity. This appears to be about the only point where the programme's supporters are prepared to concur with Sweet.

The politest reaction to the report is that where it gets its facts right it states the obvious but that overall it is essentially misconceived. "We do not consider this a particularly high-quality review," said an official. "There are some points that are valid but I do not thionk the man really understood the problems." Fusion's proponents say that the programme is being undertaken in the full expectation that it will take decades to overcome the enormous technical hurdles, and that comments in the report belie a fundamental misunderstanding of the programme's purpose.

Simon Hadlington

*Criteria for the Assessment of European Fusion research. STOA project, European Parliament Luxembourg. 10 ECU. 